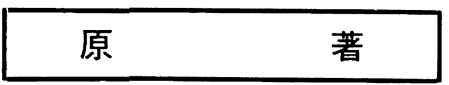

\title{
過去11年間の歯学部学生歯内治療臨床実習の統計学的検討
}

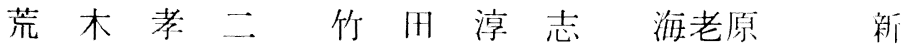 \\ 松本宏之須田英明 \\ 東京医科歯科大学齿学部第 3 歯科保存学教室 (主任 : 須田英明教授)
}

（1991年 3 月26日 受付）

\section{Statistical Study of Endodontically Treated Teeth by Undergraduate Students from 1979 to 1989}

\author{
Kouji Araki, Atsushi Takeda, Arata Ebihara, \\ Hiroyuki Matsumoto and Hideaki Suda \\ Department of Endodontics, Faculty of Dentistry, Tokyo Medical and Dental University \\ (Chief : Prof. Hideaki Suda)
}

\begin{abstract}
In clinical education in dentistry, it is very important and significant that the undergraduate students themselves treat the patients. According to the rapid progress of dental science, the complexity and the highdegree of the quality of education increase more and more, so that it is a requisite to make our efforts to enrich the quality of the practice at all times.

In this paper, we investigated and statistically analyzed the result of 3,359 cases (test cases : 304 , general cases : 3,055 ) which were treated endodontically by the undergraduate students of Tokyo Medical and Dental University in the four classes of 1979, 1982, 1986 and 1989.

Both the number of the treated cases and the patients decreased year by year. Only the patients above sixty years old showed a tendency to increase in number. The result of the test cases was not always representative of the result of the general cases.

If the clinical instructors for the undergraduate students grasp the detailed results of this study, we can expect that they can guide and train the undergraduate students more effectively.
\end{abstract}

\section{I .はじめに}

近年, 歯科医学扣よび歯科医療の進歩・発達と 細分化には目覚ましいものがある。これに伴っ て，当然のことながら歯科大学・大学歯学部にお ける教育については質・量ともますます増大して おり，6年間といら短い修業期間内で十分な歯学 教育を行らことが困難になりつつあるのが現状で ある1)。

当教室は歯内治療学を担当しており，歯学部 2
年生には講義を，3 年生には模型実習と臨床予備 実習を，そして 4 年生には臨床総合実習と臨床選 択実習の指導を担当している。臨床総合実習の内 容は、ほほ注 1 年間にわたる臨床実㥜期間中に治療 される一般ケースと，学生 1 人 1 症例ずつ術前診 査後と根管拡大終了後に口頭で試問が行われる 試験ケースとに分けられる。この臨床総合実習 は，歯学教育に扮いて非常に重要かつ有意義なも のであるが，前述のごとく教育内容が膨潤および 複雑化するなかで，より一層充奉させていくため 
の努力を常に忘らないことが要䚴されている。こ のよらな観点から，過去に行われた臨床総合车 羽の実紸を把握・評㑛することは有意義と思われ る。

われわれの教室では，これまでに，器具の折込 2 2)，根管壁穿孔33，根管処置幽の経過観察4)な ど，一つのテーマに絞った評価は行ってきたが, 各年度間の臨床総合実㥜の矢態を比較することは 行っていなかった。そこで今回，臨床総合実習に 拈ける学生の歯内治療の実態, 実績, 一般ケース 々試験ケースとの関連性，および各データ項目間 の関連性につき調査を実施した。

\section{II. 調 查方法}

\section{1. 調查対象}

調査対象は, 昭和54年度（1979年度）から平成 元年度（1989年度）までの11年間のらち, 昭和 $54 ， 57 ， 61$, 平成元年度の計 4 年度における東京 医科歯科大学歯学部第 4 学年臨床 総合実習で行

表 1 歯内治療臨床総合头習に打ける必不共修 項目之数（もしくは点数）の变選

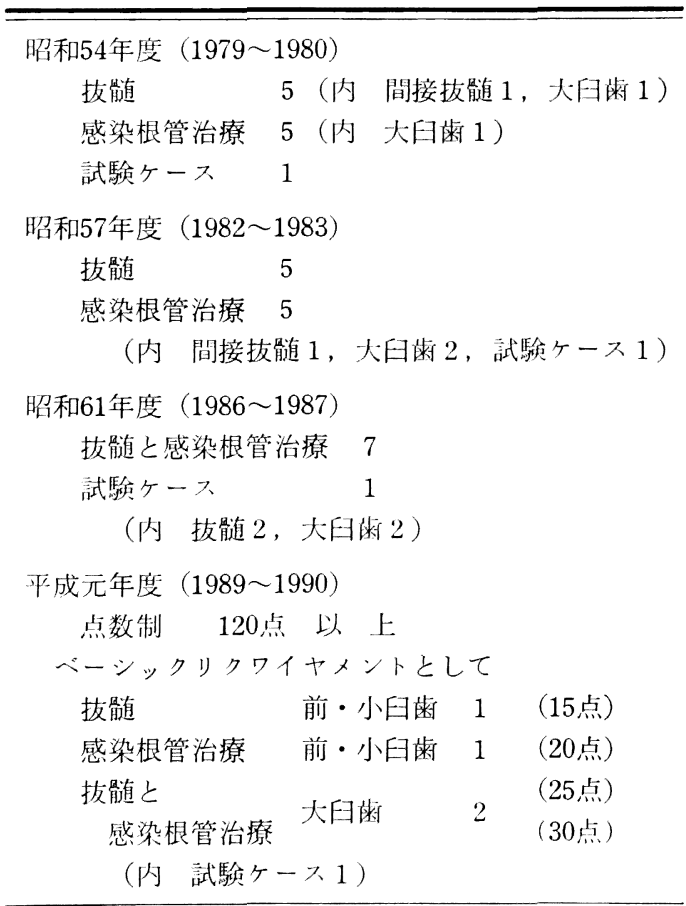

われた歯内治療の試験ケース 304 症例扣よび一般 ケース 3,055 症例の計 3,359 症例であった。なお， この 4 年度の臨床総合実習に抢ける必須履修項目 と数（もしくは点数）の変遷を表 1 に示した。昭 和 $54 ， 57 ， 61$ 年度については，若干の数の違いは あるものの，ほぼ同様のケース内容であった。ま た，昭和 $54 ， 57$ 年度では間接抜髄が 1 ケース必 須であった。平成元年度では，点数制十「Basic Requirement」といら制度に変り，前歯または 小曰歯の抜䯣と感染根管治療を各 1 症例ずつ, ま た，抜髄・感染根管治療を問わず大臼歯を 2 症例 治療し， かつ合計点数が 120 点以上になるように さらに何症例かを治療するよう改められた。

\section{2. 調查内容}

調査内容は以下のとおりである。

1）治療実績数，患者数扣よび患者年齢層の変 化

2）下記の項目における試験ケースと一般ヶー スとの関連性

i. 抎大所要時間

ii. 抎大終了までの治療回数

iii. 細菌培養回数

iv，根管充填刘到達度

v. 根管充填やり直し率

vi. 治療実日数

vii. 事故件数

これらの各項目について，試験ケースが一般ケ 一スの指標となりらるかどうかを調査した。

3）術前 X線所見ならびに臨床症状と拡大終了 までの治療回数, 細菌培養回数, 治療実日数 との関連性

\section{3. データの調査方法}

各症例ごとのプロトコールの調査については, 5 年以上の臨床経験をもつ 4 人の当教室員が各年 度を受持ち，X線写真上に拈ける根尖部透過像の 有無や根管充填片到達度の判定については事前に 打合せを行い，統一を図った。また調査途中でも 評洒に迷った場合には，その都度協議して判定し た。根管充填剤の到達度については, 術前のX線 写真上で根尖端より $0.5 \sim 1.0 \mathrm{~mm}$ 控えた根管内に 
止まっているものを適正根充 (flush)，それより も短いものを不足根充 (under), 長いものを過剩 根充 (over) と判定した。また複根歯の場合は, 一根管でも flush でないものがある場合には, over または under と判定し，どれか一根管でも over のものがあれば over と判定した。

今回の調査では, 拡大終了までの治療回数之は 細菌培養検査を行う前までの治療回数とし, 治療 実日数とは良好な予後成績が確認できた日を含め た治療回数とした。また，事故の発生について は, リーマー等の根管拡大用器具の折込又と, 穿 孔の二種類について調査した。

\section{III. 結 果}

\section{1. 治療実績数, 患者数および患者年齢層の变化}

表 2 は, 治療実績数の変化をまとめたものであ
表 2 治療実績数の変化

\begin{tabular}{|c|c|c|c|c|}
\hline & S 54 & S 57 & S 61 & $\mathrm{H} 1$ \\
\hline 学生数 & 78 & 77 & 80 & 76 \\
\hline ケース総数 & $1,052(13.5)$ & $794(10.3)$ & $804(10.0)$ & $709(9.3)$ \\
\hline 直接抜㭏直 & $439(5.6)$ & $311(4.0)$ & $288(3.6)$ & $278(3.6)$ \\
\hline 間接抜䯣 & $83(1.0)$ & $82(1.1)$ & $1(0.0)$ & $0(0.0)$ \\
\hline 感染根管治療 & $530(6.7)$ & $401(5.2)$ & $515(6.4)$ & $431(5.7)$ \\
\hline 大臼歯 & $400(5.1)$ & $388(4.4)$ & $337(4.2)$ & $311(4.1)$ \\
\hline 小臼歯 & $335(4.3)$ & $247(3.2)$ & $216(2.7)$ & $217(2.8)$ \\
\hline 前 歯 & $317(4.1)$ & $209(2.7)$ & $251(3.1)$ & $181(2.4)$ \\
\hline
\end{tabular}

る。括弧内は, 学生 1 人当りの平均実績数であ る。昭和 54 年度（S54）は13.5ケースであるが， 以後徐々に減少しており, 平成元年度 (H 1) で は9.3ケースであった。
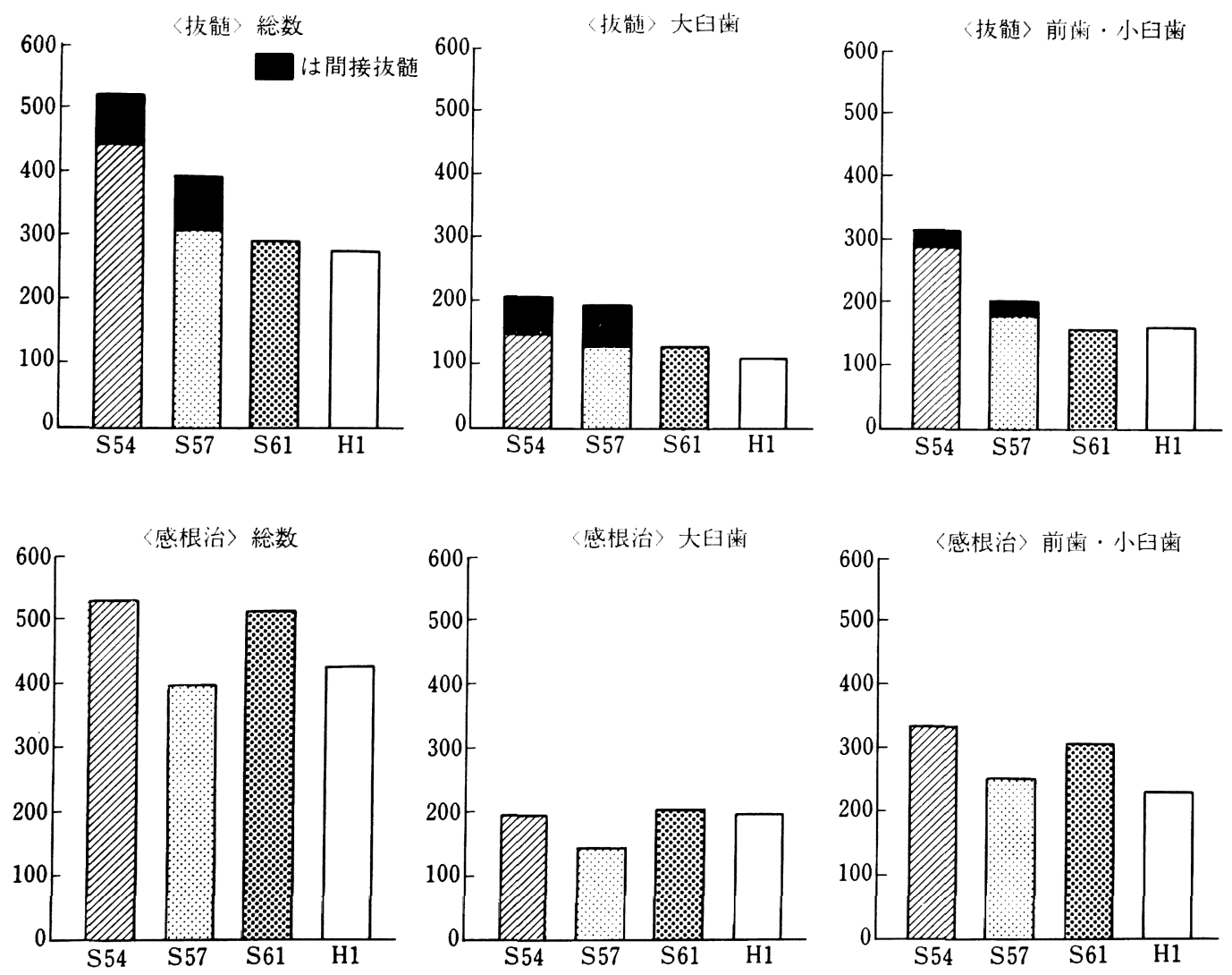

図 1 歯種別治療実績数の变化 
図 1 は, 歯種別のケース数の変化をグラフにし たものである。どの年度に拈いても直接抜髄より 感染根管治療（感根治）の注うが 90 ケース以上多 く行われていた。

表 3 は，患者数の变化をまとめたものである。 括弧内は, 学生 1 人当りの患者数である。平成元 年度は, 昭和 54 年度のほぼ半数になっていること が分かった。また患者 1 人当りのケース数を久て も, 昭和 54 年度が 1.44 であるのに対し, 平成元年 度は1. 61 と約 $12 \%$ 增光ていた。
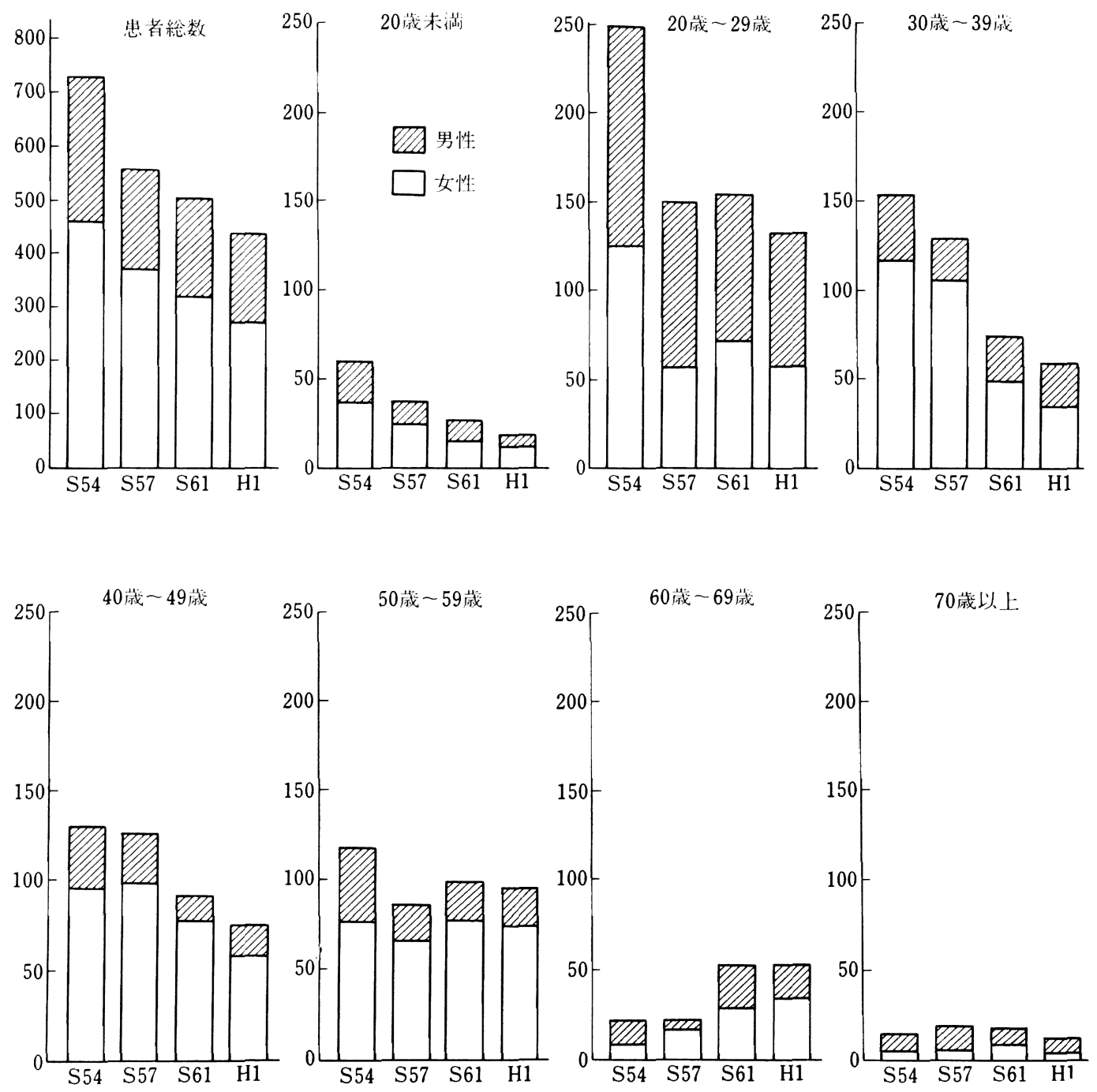

図 2 年龄別の患者数の变化 


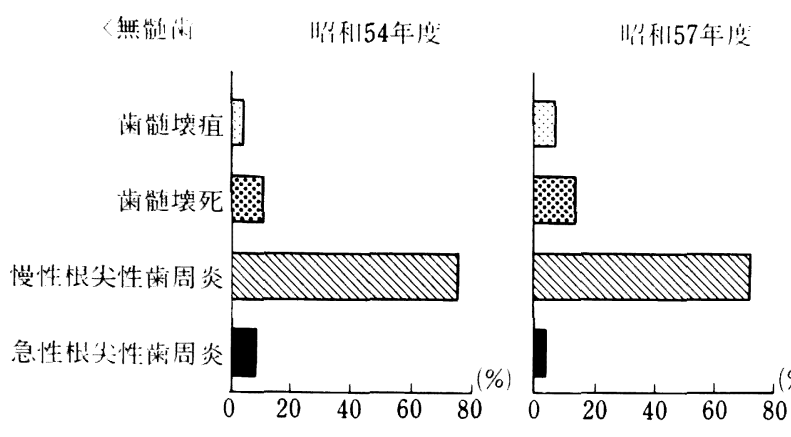

(\%)

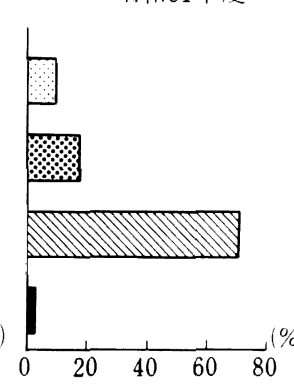

怕成元年度:
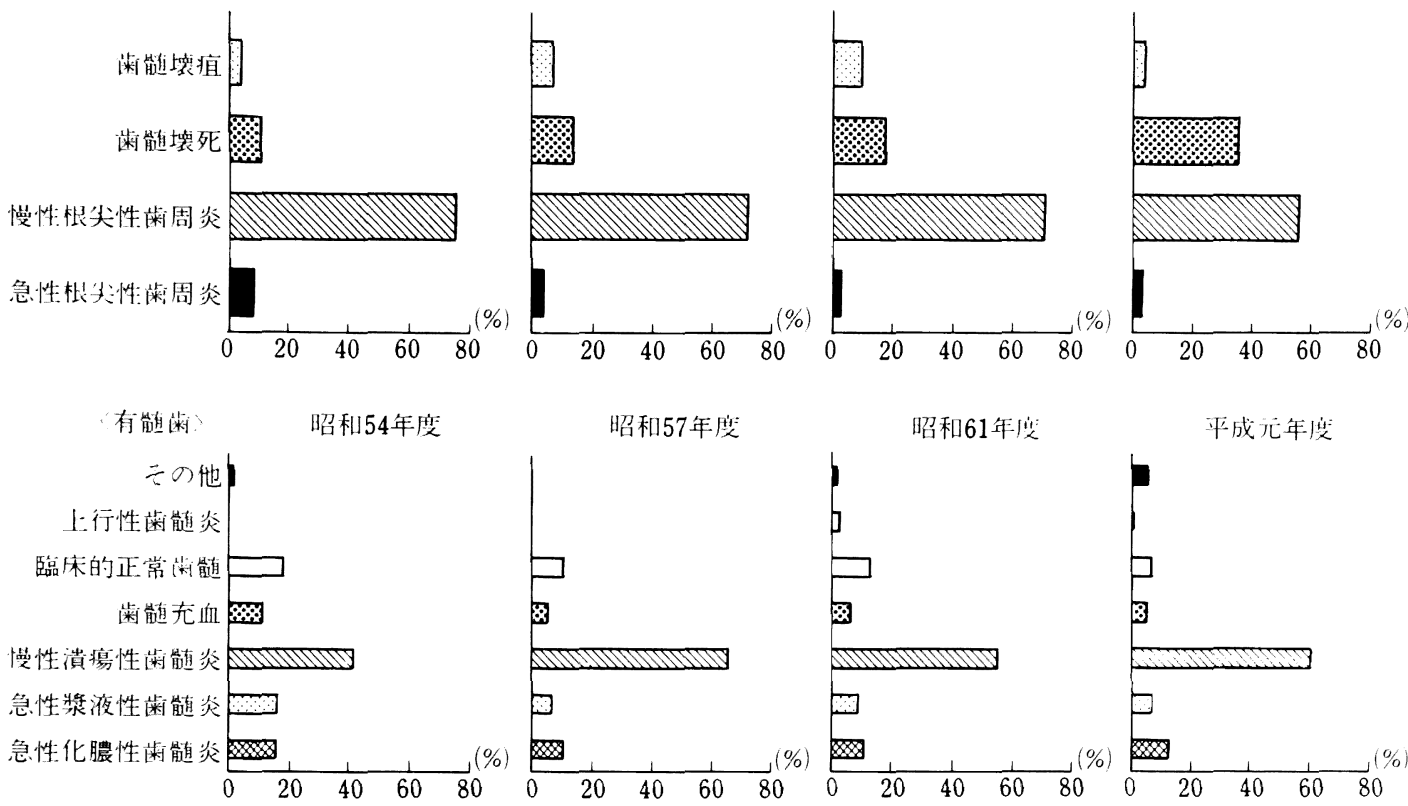

図 3 臨床的骖断名別の症例数の比率

図 2 は，患者数の変化を年蛉別にグラフで示し たものである。50墄末満の患者数は年々減少して いたのに対し，60歳以上の患者数は逆に増加して いた。また，どの年度に拈いても患者総数として は男性よりも女性のほらが多く、注ぼ60６5\%を 女性が占めていたが，20歳代の患者については， 逆に男性のほうが多かった。

図 3 は, 臨床的診断名別の症例数の比率を各年 度ごとにグラフに示したものである。無㵦歯で は，どの年度においても慢性根尖性歯周炎が全体 の50〜70\%を占めていた。また有髄歯では，慢性

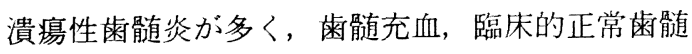
と合わせると，どの年度においても全体の約 $70 \%$ を占めていた。

\section{2. 試験ケースと一般ヶースとの関連性}

表 4〜 7 は, 拡大所要時間, 拡大終了までの治 療回数, 細菌培養回数, および治療実日数につい て, 試験ケースと一般ケースの各年度に打ける平 均值と標準偏差を示している。両群の差の検定を Student-t-testにより行った。その結果, 細菌 培養回数については, 直接抜髄, 感染根管治療と
表4 試䮖ケースと一般ケースの閶連性 (扗大所要時間)

\begin{tabular}{|c|c|c|}
\hline & 試験ケース & 一般ケース \\
\hline \multicolumn{3}{|l|}{ 直接抜䯣 } \\
\hline S 54 & $73.28 \pm 51.13$ (分) & $70.58 \pm 59.69$ (分) \\
\hline S 57 & $74.08 \pm 36.13$ & $85.29 \pm 84.78$ \\
\hline S 61 & $115.50 \pm 68.55^{*}$ & $82.19 \pm 71.71$ \\
\hline $\mathrm{H} 1$ & $140.00 \pm 97.04 \#$ & $98.80 \pm 93.16$ \\
\hline \multicolumn{3}{|l|}{ 感染根管治療 } \\
\hline S 54 & $73.00 \pm 57.14$ (分) & $83.54 \pm 91.17$ (分) \\
\hline S 57 & $111.77 \pm 72.39 *$ & $76.88 \pm 62.74$ \\
\hline S 61 & $130.40 \pm 92.02 \#$ & $89.25 \pm 77.30$ \\
\hline $\mathrm{H} 1$ & $171.35 \pm 161.56$ & $148.81 \pm 149.90$ \\
\hline
\end{tabular}

も試験ケースと一般ケースとの間にどの年度にお いても有意差は認められなかったが，抎大所要時 間, 拡大終了までの治療回数, および治療実日数 については, 直接抜髄, 感染根管治療とも 4 年度 のらちで試験ケースと一般ケースとの間に有意差 が認められる場合と認められない場合があった。

表 8 は, 再根管充填を行った数, 表 9 は, 根管 
表 5 試験ケースと一般ケースの関速性 （扗大終了までの治療回数）

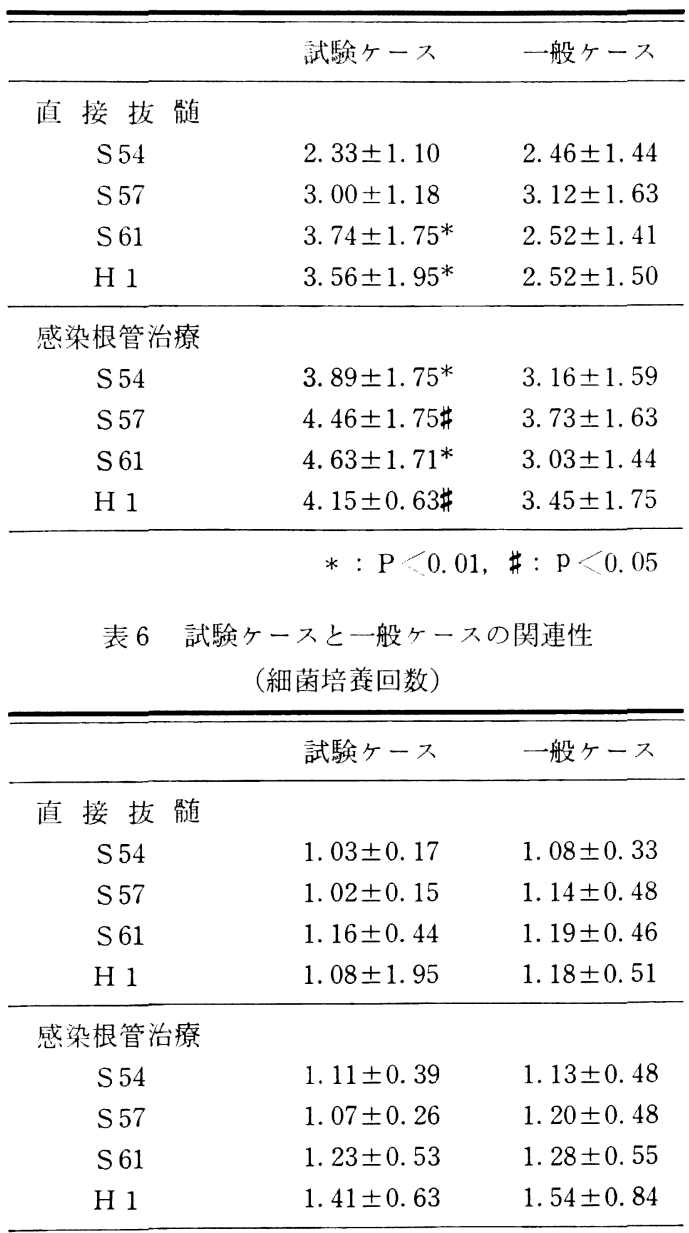

充填剂到達度について，四つの年度を合計したも のである。それぞれ $2 \times 2 ， 3 \times 2$ の分割表によ る $\chi^{2}$ 検定を行ったところ, 根管充填荗到達度に 関して，感染根管治療の場合の久危険率 $5 \%$ で有 意差が認められた。

表10は，事故件数についてのまとめである。リ 一マー等の折込みは抜髄のほうが多く, 穿孔は逆 に感染根管治療のほうが多かった。

3. 術前の X 線所見ならびに臨床症状と拡大終了ま での治療回数, 細菌培養回数, 治療実日数との関 連性

表11は，拡大終了までの治療回数，治療実日数
表 7 試験ヶースと一般ヶースの関連性 (治療军日数)

\begin{tabular}{ccc}
\hline & 試験ケース & 一般ケース \\
\hline 直 接 拔 髄 & & \\
S 54 & $5.31 \pm 1.31$ & $5.82 \pm 1.75$ \\
S 57 & $6.66 \pm 2.23$ & $6.55 \pm 2.08$ \\
S 61 & $7.21 \pm 1.85^{*}$ & $6.17 \pm 1.94$ \\
H 1 & $6.61 \pm 2.48$ & $5.86 \pm 2.21$ \\
\hline
\end{tabular}

感染根管治療

\begin{tabular}{lll} 
S 54 & $6.82 \pm 1.80$ & $6.52 \pm 1.85$ \\
S 57 & $7.75 \pm 1.92$ & $7.08 \pm 1.99$ \\
S 61 & $8.05 \pm 1.74^{*}$ & $6.76 \pm 1.93$ \\
H 1 & $7.56 \pm 1.87$ & $7.42 \pm 2.42$ \\
\hline & & $*: \mathrm{p}<0.01$
\end{tabular}

表 8 試験ヶースと一般ケースの関連性 （再根管充填を行った数）

\begin{tabular}{|c|c|c|c|}
\hline & & 試験ケース・抜髄 & 一般ヶース・抜䯣 \\
\hline あ & $\eta$ & $20(12.7 \%)$ & $203(15.3 \%)$ \\
\hline な & L & $137(87.3 \%)$ & $1,122(84.7 \%)$ \\
\hline \multirow[t]{3}{*}{ 合 } & 計 & $157(100 \%)$ & $1,325(100 \%)$ \\
\hline & \multicolumn{3}{|c|}{ （数字は間接拔㭪道を含む） } \\
\hline & & 試騟ケース・感根治 - & 一般ケース・感根治 \\
\hline あ & $\eta$ & $14(9.5 \%)$ & $190(11.0 \%)$ \\
\hline な & し & $133(90.5 \%)$ & $1,540(89.0 \%)$ \\
\hline 合 & 計 & $147(100 \%)$ & $1,730(100 \%)$ \\
\hline
\end{tabular}

および細菌培養回数を, 術前のX線所見ならびに 臨床症状の相違によって区分し，それぞれ四つの 年度の平均值と標準偏差を示したものである。両 群の差の検定を Student-t-test により行った。 その結果，抜䯣に打いては，術前のX線所見なら びに臨床症状の相違と各項目間には全く有意差は 認められなかった。これに対し，感染根管治療に おいては，X線透過像の有無と拡大終了までの回 数, 術前の根管治療の有無と細菌培養回数, 根分 岐部病変の有無と 3 項目すべて，瘦孔の有無と拡 大終了までの回数および細菌培養回数との間に有 意差が認められた。 
表 9 試験ケースと一般ケースの関連性

（根管充塓剂到達度）

\begin{tabular}{|c|c|c|}
\hline & 試験ケース・拔噵 & 一般ヶース・拔憱 \\
\hline under & $44(28.0 \%)$ & $444(33.6 \%)$ \\
\hline flush & $54(34.4 \%)$ & $496(37.5 \%)$ \\
\hline over & $59(37.6 \%)$ & $381(28.9 \%)$ \\
\hline 合計 & $157(100 \%)$ & $1,321(100 \%)$ \\
\hline
\end{tabular}

\begin{tabular}{lrc}
\hline & 試験ケース・感根治 & 一般ヶース・感根治 \\
\hline under & $52(35.9 \%)$ & $637(37.0 \%)$ \\
\hline flush & $38(26.2 \%)$ & $587(34.0 \%)$ \\
\hline over & $55(37.9 \%)$ & $499(29.0 \%)$ \\
\hline 合計 & $145(100 \%)$ & $1,723(100 \%)$ \\
\hline & & $P<0.05$
\end{tabular}

IV. 考察

「雬学教育の改善に関する調査研究協力者会議 の最終まとめ」5) に述べられているように，臨床 実㥜に招いては単に科目別の歯科医療技術のみを 習得させるのではなく，全身的見地に立って患者 の心身を捉えていくようにさせることが大切であ る。しかし歯学教育のなかで, 知識・技能の習得 もまた重要であり, 臨床実習の場で学生になるべ く多くの患者, 多椂な症例に遭遇させ, 実技の機 会を与学ることが求められる。ところが，近年の 歯学教育を取巻く環境の変化, とりわけ歯科医学 の急速な高度化・細分化, 患者側の霜科医療に対 する意識変革, 疾病構造そのものの変化等の理由 により，卒前の患者臨床実習のあり方が問われて いる。このような状沉のなかで，少しでも臨床実 習の内容を充実させ，教育効果を向上させていく 表10 試験ケースと一般ケースの関連性

(事故件数)

拔鹃道

\begin{tabular}{|c|c|c|c|c|c|c|}
\hline & \multicolumn{2}{|c|}{ 試験ケース } & \multicolumn{2}{|c|}{ 一般ヶース } & \multirow{2}{*}{\begin{tabular}{c} 
合 \\
\hdashline$y-マ-$ 折込
\end{tabular}} & \multirow{2}{*}{\begin{tabular}{l} 
計 \\
\hdashline 穿
\end{tabular}} \\
\hline & リーマー折込 & 穿孔 & リーマー折込 & 穿孔 & & \\
\hline S 54 & 1 & 0 & 6 & 4 & 7 & 4 \\
\hline S 57 & 3 & 0 & 3 & 0 & 6 & 0 \\
\hline S 61 & 0 & 0 & 0 & 1 & 0 & 1 \\
\hline H 1 & 0 & 0 & 2 & 3 & 2 & 3 \\
\hline 合 計 & 4 & 0 & 11 & 8 & $\begin{array}{c}15 \\
(1.0 \%)\end{array}$ & $\begin{array}{c}8 \\
(0.54 \%\end{array}$ \\
\hline
\end{tabular}

（）は拔咀総数 1,482 に対する百分率

感染根管治療

\begin{tabular}{|c|c|c|c|c|c|c|}
\hline & \multicolumn{2}{|c|}{ 試駼ケース } & \multicolumn{2}{|c|}{ 一般ヶース } & \multirow{2}{*}{$\begin{array}{c}\text { 合 } \\
\text { リ-マー折込 }\end{array}$} & 計 \\
\hline & リーマー折込 & 穿孔 & リーマー折込 & 穿孔 & & 穿 \\
\hline S 54 & 0 & 1 & 1 & 3 & 1 & 4 \\
\hline S 57 & 2 & 0 & 2 & 4 & 4 & 4 \\
\hline S 61 & 0 & 0 & 1 & 10 & 1 & 10 \\
\hline H 1 & 0 & 1 & 3 & 8 & 3 & 9 \\
\hline 合 計 & 2 & 2 & 7 & 25 & $\begin{array}{c}9 \\
(0.48 \%)\end{array}$ & $\begin{array}{c}27 \\
(1.4 \%)\end{array}$ \\
\hline
\end{tabular}

（）は感染根管治療総数 1,877 に対寸る百分率 
表11 各項目間の関連性（各年度の合計）

拔路道

\begin{tabular}{|c|c|c|c|c|c|c|}
\hline & X線王 & 鸟像 & 根分崻 & 病変 & 根尖部自 & 肉腫脹 \\
\hline $\begin{array}{l}\text { 扗大終了まで } \\
\text { の治療回数 }\end{array}$ & $2.72 \pm 1.56$ & $2.64 \pm 1.49$ & $3.34 \pm 1.45$ & $3.49 \pm 1.67$ & $2.94 \pm 1.85$ & $2.65 \pm 1.49$ \\
\hline 治療実日数 & $5.93 \pm 1.89$ & $6.07 \pm 2.24$ & $6.59 \pm 1.54$ & $6.98 \pm 2.35$ & $5.88 \pm 2.15$ & $6.06 \pm 2.20$ \\
\hline 槒菌培靕回数 & $1.12 \pm 0.37$ & $1.11 \pm 0.41$ & $1.12 \pm 0.33$ & $1.11 \pm 0.37$ & $1.02 \pm 0.30$ & $1.02 \pm 0.41$ \\
\hline
\end{tabular}

感染根管治療

\begin{tabular}{|c|c|c|c|c|c|c|c|c|c|c|}
\hline & X線透 & 過像 & 根管 & 治療 & 根分岐 & 部病変 & 瘦 & 孔 & 根尖部占 & 肉腫脹 \\
\hline & & & & & & & & - & & \\
\hline $\begin{array}{l}\text { 挔大終了まで } \\
\text { の治療回数 }\end{array}$ & $3.10 \pm 1.58^{*}$ & $3.31 \pm 1.68$ & $3.12 \pm 1.60$ & $3.25 \pm 1.60$ & $4.33 \pm 1.75^{*}$ & $3.72 \pm 1.75$ & $3.58 \pm 1.94 *$ & $3.14 \pm 1.59$ & $3.48 \pm 1.73$ & $3.14 \pm 1.61$ \\
\hline 治療実日数 & $6.69 \pm 2.01$ & $6.80 \pm 1.97$ & $6.73 \pm 2.03$ & $6.71 \pm 1.93$ & $8.26 \pm 2.31^{*}$ & $7.25 \pm 2.04$ & $7.17 \pm 2.20$ & $6.69 \pm 1.98$ & $7.09 \pm 2.15$ & $6.69 \pm 1.98$ \\
\hline 細菌培養回数 & $1.27 \pm 0.59$ & $1.25 \pm 0.61$ & $1.29 \pm 065 \#$ & $1.22 \pm 0.50$ & $1.44 \pm 0.84^{*}$ & $1.25 \pm 0.54$ & $1.37 \pm 0.78$ & $1.25 \pm 0.58$ & $1.29 \pm 0.61$ & $1.26 \pm 0.60$ \\
\hline
\end{tabular}

ためには，過去の実績を絶它ず把握し評価するこ とにより，現状を理解し，将来を見通す作業が必 要と思われる。

今回, 過去11年にわたる歯内治療学の臨床総合 実習の実態を調查した結果，夹習の現場にある指 導教官が毎年のように指摘する事柄が，具体的な 数值として客観的に表されたことは興味墚い。

平均治療実績数が経年的に減少していたが，こ れは学生に課した必須履修項目と数（もしくは点 数）が減少したといら直接の理由もさることなが ら，学生に配当できる患者数が年々減少している ことも考虑すべきことであろう。しかし，症例は あっても治療はしないといら消極的態度あるいは 将来の歯科医師を目指す目的意識に欠けるといわ れる近年の料科学生の気質の現れと考克られる部 分も否定できない。このよらな学生に対しては, 学生臨床実習の管理者および現場の指導教官側の 意識を, 待機的なものから能動的なものへと変化 させることにより，学生の履修意欲をより積極的 なものへ変えることができるのではないかと思わ れる。

歯種別のケース数を調べた結果，どの年度にお いても，拔髄より感染根管治療の症例が多かっ た。この理由は䛦断名別症例数の絬果からも推察 できる。すなわち，拔䯙ではどの年度でも慢性潰

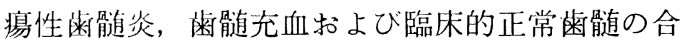
計症例数が抜骾総数の約 7 割を占め, 急性化膿性 歯髄炎や急性漿液性歯髅炎の症例は約 $2 \sim 3$ 割で ある。これは本学歯学部附属病院を訪れる新患の うち, 怘性症状のある患者は, 学生が扱う症例と して必ずしも適当でないという理由で除外される ことが多いからである。感染根管治療のなかで, 急性根尖性歯周炎の治療が総数の約 $3 \%$ 程度しか 行われていないのも, 全く同じ理由である。し かしこのことは卒前の臨床実習に拈いて，急性症 状を有する症例を経験できない学生が少なくない ことを示している。迅速で正確な診断と, 緊急処 置を要するこれらの症例への対応を, どのように 臨床実習のなかに組込んでいくかは今後検討すべ き課題である。

年齢別に患者数の変化をみると, 高秢化社会の 波が雨内治療臨床実習の患者にも押寄せているこ とが明瞭である。しかし，高齢の歯科患者は，何 らかの全身疾患を有している場合が多いこと, 過 去に粦内治療を受けた齿の再治療が多いこと，あ るいは歯髄の石灰変性や歯髄腔の狭窄が著しいこ となど，治療の困難性が若い患者に比べてはるか に高く，患者の状態や処置内容によっては全身管 理を行わなくてはならない場合も考えられる。卒 前の臨床実習においても，このような高歯患者に 
対する特別な教育を行う必要性が感じられる。東 京医科歯科大学歯学部に拈いても，高齢者歯科学 講座が設立され，ようやく老年歯科医学の教育が 始まったばかりである。また，今後とくに必要と されるのは，大学病院以外の臨床実習の実施場所 をどのように確保し，そしてどのように活用して いくかであろら。なぜならば, 大学病院では、リ スクの高い老年者やボケあるいは痴呆といった老 年者を経験する機会が少ないからである6)。

臨床実習に括ける各年度間の比較は教育効果の 評価を行う祭，非常に重要である。しかし，年々 症例数が減っているとはいえ，毎年 700 以上の症 例すべてについて比較することは困難がある。そ こで今回，学生が必ず 1 症例行うことになってい る試験ケースの結果が，一般ケースの指標となり えないかと考穴て，この両群につき各項目間での 関連性を統計学的に調べてみた。その結果, 細菌 培養回数を除いては，根管拡大所要時間，抎大終 了までの治療回数，扣よび治療実日数について は, 年度によって統計学的に有意差がみられると きとみられないときがあった。また四つの年度の 合計で比較した再根管充填歯数については，抜 骮连，感染根管治療とも両群間に有意差がなかっ た。しかし根管充填剂到達度では，抜髄症例では 両群間に有意差がみられないものの, 感染根管治 療症例では，両群間に有意差が認められた。した がって, 今回比較した各項目については, 試験ヶ 一スの結果が必ずしも一般ケースを代表していな いといえよう。“試験”となると, 学生が一般ケー ス以上に慎重に時間をかけて治療を行らことが最 大の理由であろら。

今回調査した事故の種類はリーマー等の折込及 と根管壁あるいは髄床底への穿孔の二種類であっ たが，この事故件数に関しては特別な扱いが必要 である。なぜなら，もしこのような事故が生じた 場合, 試験ケースはその性格上, 再試験になるこ とが多く，事故を起こした症例は履修ケースとし て認定されないか一般ケースとして扱われてい る。また，一般ケースでもプロトコールが提出さ れないこともあるのが実情である。そのため, 事
故件数について，試験ケースと一般ヶースを比較 することは困難である。両群の合計として事故件 数をみたとき，抜髄ではりーマー等の折込みが多 く, 感染根管治療では逆に穿孔が多い結果であっ た。新田ら 2) は, 学生が行った 7 年間の歯内治療 症例を調べた結果, 根管内への器具の折込みにつ いて抜髄では1.10\%，感染根管治療では1.63\%で あったと報告している。また，㨗養ら゙3 は同様の 調查で根管壁穿孔について, 抜髄では8. $26 \%$, 感 染根管治療では $11.32 \%$ であったと報告してい る。これは今回のわれわれの調查結果と比べて, 特に根管壁穿孔については異常に高い数字といえ る。しかし撫養らの調査では，根尖部に打いて主 根管を外れて根管充填が施されている症例をすべ て根管壁穿孔として扱って打り，われわれとの評 価基準が異なり，このような高い比率となったも のと考えられる。

一方, 術前の X線所見ならびに臨床症状と各項 目間の関連性の結果から, 感染根管治療に打いて は, 術前診査で根分岐部病变や瘦孔が認められた 場合には, 拡大終了回数, 治療実日数, 細菌培養 回数などが多くなる傾向があった。これに対し て，抜髄では，特にそのような関連性は認められ なかった。感染根管治療において治療回数が多く なる要因として，歯種，X線透過像の有無，自発 痛等の術前の症状，根管内病原因子，あるいは治 療操作に関する因子など，いろいろなものがあげ られているが7)，これらの因子が根管充填後の長 期的な経過とどのように関係していくのか，特に 学生が行った治療はどのような経過をたどってい くのか, 興味深い問題である。今後, 患者のリコ 一ル等を行い, この点について子解明していく必 要があろう。

\section{V.おわりに}

昭和 54 年度から平成元年度までの 11 年間のうち 昭和 $54,57,61$, 平成元年度の 4 年度に扮ける東 京医科歯科大学霜学部第 4 学年の䨑内治療臨床奏 習の試験ケース304症例, 一般ケース 3,055 症例の 計 3,359 症例の全プロトュールについて調査を行 
い,以下の結論を得た。

1）治療実績数，患者数ともに経年的に減少し ていた。ただし，60歳以上の高路患者数のみは増 加傾向にあった。

2）今回比較した根管拡大所要時間, 拡大終了 までの回数, 治療実日数などについては, 試験ケ 一スの結果が必ずしも一般ヶースを代表している とはいえなかった。

3）感染根管治療において, 術前の診查で根分 岐部病変や瘦孔が存在していた症例では, 拉大終 了までの治療回数, 治療丰日数, および細菌培盖 回数が，多くなる傾向があった。

\section{文献}

1）黑崎紀正：歯科臨床教育の現状と問題点. 口病 誌 $56(3): 403-408,1989$.

2）新田光朗, 㨨坫勉成, 野田和棇, 松元 壬: 根 管治療に拈ける器具の折れこみについて 第 2
報 患歯の予後成績について，日歯保誌 19 (1) : 73-80, 1976.

3）撫養勉成, 新田光朗, 野田和稳, 松元 仁: 根 管治療に拈ける根管壁穿孔症例について一患歯 の予後成績について一。目歯保誌 $19(2): 361$ $-367,1976$.

4) 山本敏夫, 吉野英明, 竹内郁子, 中島捷行 : 根 管処置歯の経過観察之統計処理（東京医科歯科 大学昭和 50 年度歯内療法卒業試験ヶースについ て). 口病誌 45(1): 90-99, 1978.

5）小椋秀亮：「歯学教育の改善に関する調查研究 協力者会議の最終まとめ」について。 日歯教誌 4(1) : 3-13, 1989 .

6）渡辺郁馬, 和田知雄, 長尾正悪, 稲葉 繁, 新 庄文明, 久保田康耶：“老年歯科医学”教育のあ り方. 日歯教誌 5(1)：19-35, 1990.

7) 戸田比佐志, 三木靖夫, 伊藤哲夫, 島袋善夫, 弓立 淳, 福原弘喜, 信田周一, 恵比須繁之, 岡田 宏: 感染根管内の病原因子の臨床的評価 一歯内治療が長びく臨床的要因一. 日歯保誌 28(2) : 791-801, 1985. 